\title{
BODY BUILD OF ELITE JUNIOR TAEKWONDO ATHLETES
}

\author{
W. Pieter \\ Department of Physical Education, \\ University of Asia and the Pacific, Pasig City, Philippines
}

\begin{abstract}
The purpose of this study was to assess and compare the somatotype of elite junior taekwondo athletes. Subjects (9 boys, $15.44 \pm 1.21$ years, $165.94 \pm 12.82 \mathrm{~cm}, 53.82 \pm 13.41 \mathrm{~kg}$, and 9 girls, $15.05 \pm 1.30$ years, $160.82 \pm 10.46 \mathrm{~cm}, 50.58 \pm 10.41 \mathrm{~kg}$ ) were members of the US national junior taekwondo team. The Heath-Carter somatotype method was used to assess body build of the athletes. To determine the difference between boys and girls in somatotype, a 1-way Anova was used. The global somatotype analysis revealed no difference in somatotype attitudinal mean between boys and girls $\left(\mathrm{p}=0.411\right.$, eta $^{2}=$ $0.043)$ or SAD $\left(p=0.215\right.$, eta $\left.{ }^{2}=0.094\right)$. There was a small difference in endomorphy between boys and girls $\left(p=0.053\right.$, eta $\left.{ }^{2}=0.214\right)$. Physique may be used as one of the selection criteria to detect and develop talent in taekwondo.
\end{abstract}

Key words: body, build, taekwondo

\section{INTRODUCTION}

Physical characteristics are believed to contribute to sports performance. For instance, elite female volleyball players were found to be taller than their colleagues in basketball and handball, with the least amount of body fat and a balanced mesomorphic body build [2]. Sexual dimorphism in somatotype was found in elite volleyball players by Gualdi-Russo and Zaccagni [13], while Wassmer and Mookerjee [26] reported more fat in elite female field hockey goalkeepers. Ho- 
wever, there were no differences between playing positions in height, lower limb length, grip strength, agility and other motor abilities.

Anthropometric studies on combat sports are scarce. Katic [14] found adult elite karate athletes (karateka) to be predominantly characterized by a mesomorphic physique and transverse skeletal dimensionality. Fritzsche and Raschke [12] reported German adult male elite karateka to have a Heath-Carter somatotype of 2.0-3.7-2.7 and their female counterparts, of 3.4-2.4-2.4.

Few studies are available on the somatotypes of taekwondo athletes (taekwondo-in). For instance, American elite adult taekwondo-in were reported to have a somatotype of 1.65-4.53-3.59 (men) and 2.083.23-3.98 (women) [25]. Pieter [19] revealed similar physiques for elite taekwondo-in: 1.74-4.68-3.02 (men) and 2.47-3.08-3.47 (women).

Adolescent taekwondo-in were investigated by Pieter [19], who reported a somatotype of 2.02-3.96-4.26 for boys and of 2.78-3.263.83 for girls. In a more recent study, Pieter [20] revealed girls to score higher in endomorphy (3.2 vs. 2.3$)$, while the boys were more mesomorphic ( 4.2 vs. 3.4$)$. There was no difference in ectomorphy: 3.5 and 3.1 for the boys and girls, respectively. In view of the lack of research on young taekwondo-in, the purpose of the current investigation was to describe and compare the somatotypes of male and female junior elite taekwondo athletes.

\section{METHODS}

Subjects (9 boys, $15.44 \pm 1.21$ years, $165.94 \pm 12.82 \mathrm{~cm}, 53.82 \pm$ $13.41 \mathrm{~kg}$, and 9 girls, $15.05 \pm 1.30$ years, $160.82 \pm 10.46 \mathrm{~cm}, 50.58 \pm$ $10.41 \mathrm{~kg}$ ) were members of the US national junior taekwondo team. Table 1 displays the taekwondo training details of the athletes.

Table 1. Means and standard deviations of training details of elite junior taekwondo-in

\begin{tabular}{|l|c|c|}
\hline & Boys & Girls \\
\hline $\begin{array}{l}\text { Taekwondo experience } \\
\text { (years) }\end{array}$ & $6.80 \pm 2.94$ & $5.29 \pm 1.13$ \\
\hline Training days/week & $4.78 \pm 1.30$ & $4.89 \pm 0.78$ \\
\hline Training times/day & $1.67 \pm 0.71$ & $1.33 \pm 0.71$ \\
\hline Hours/session & $2.00 \pm 0.66$ & $2.17 \pm 1.30$ \\
\hline
\end{tabular}


Height was measured by means of a wall-mounted wooden stadiometer to the nearest $1 \mathrm{~cm}$ and an electronic weighing scale was used to assess body mass to the nearest $0.5 \mathrm{~kg}$. Skinfold thicknesses were taken at the following sites with a Lange caliper: triceps, subscapular, supraspinale, and medial calf. In addition, biepicondylar widths of the humerus and femur were taken as well as the girths of the flexed and tensed upper arm and calf. The median was used for statistical analysis if the measurements had to be taken three times, while the mean was utilized if the first two measurements were within the acceptable range [22]. The Heath-Carter method was used to estimate somatotype [7].

To determine the difference between boys and girls in somatotype, a 1-way Anova was used. The level of significance was set to 0.05 . It was decided not to adjust the type 1 error for multiple comparisons, because the interest was in the comparisonwise error rate as the data were generated through actual observations. The objective was to unearth any possible leads regarding the relationship between the independent and dependent variables $[3,23]$.

\section{RESULTS}

There were no differences between boys and girls in age $(\mathrm{p}=0.512$, eta $\left.^{2}=0.027\right)$, height $\left(p=0.367\right.$, eta $\left.^{2}=0.051\right)$ and weight $(p=0.574$, eta $^{2}=0.020$ ). Table 2 shows the descriptive statistics of the somatotypes of the junior taekwondo-in. The global somatotype analysis revealed no difference in SAM between boys and girls $\left(\mathrm{p}=0.411\right.$, eta $^{2}$ $=0.043)$ or $\operatorname{SDM}\left(\mathrm{p}=0.215, \operatorname{eta}^{2}=0.094\right)$.

Table 2. Means and standard deviations of somatotypes in elite junior taekwondo-in

\begin{tabular}{|l|c|c|}
\hline & Boys & Girls \\
\hline Endomorphy & $2.19 \pm 0.70$ & $2.88 \pm 0.69$ \\
\hline Mesomorphy & $3.96 \pm 0.82$ & $3.24 \pm 1.03$ \\
\hline Ectomorphy & $3.83 \pm 0.94$ & $3.41 \pm 1.01$ \\
\hline SAM & $1.19 \pm 0.68$ & $1.43 \pm 0.50$ \\
\hline SDM & $2.80 \pm 1.66$ & $3.81 \pm 1.64$ \\
\hline
\end{tabular}


There was a small difference in endomorphy between boys and girls $\left(\mathrm{p}=0.053\right.$, eta $\left.^{2}=0.214\right)$. No differences were found in mesomorphy $\left(p=0.124\right.$, eta $\left.^{2}=0.141\right)$ and ectomorphy $\left(p=0.373\right.$, eta $\left.{ }^{2}=0.050\right)$.

Figure 1 depicts the somatoplots of both boy and girl taekwondoin. There was a $33 \%$ overlap of girls with boys.

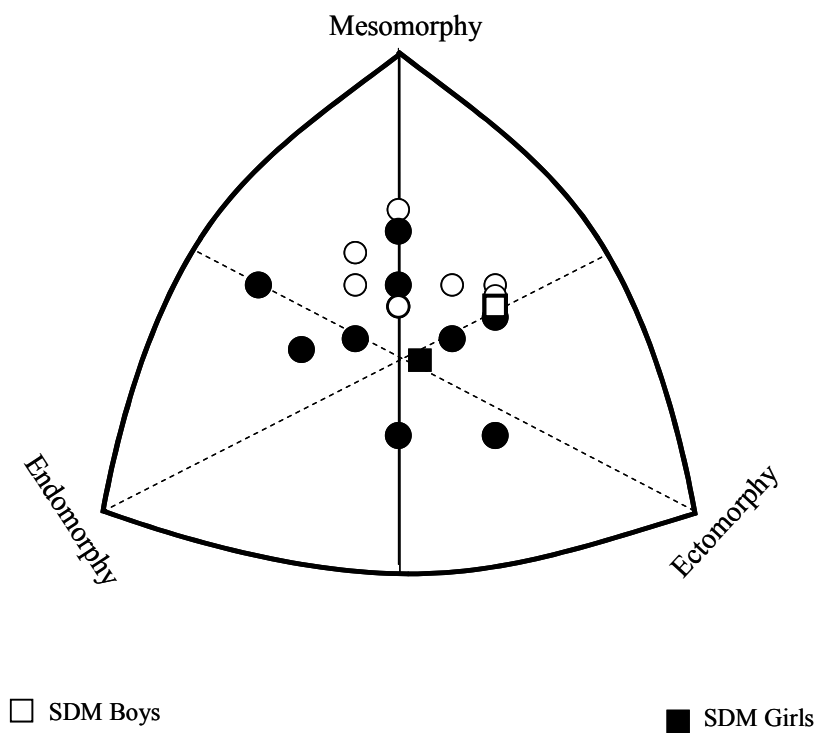

Figure 1. Somatoplots of boy and girl taekwondo-in

\section{DISCUSSION}

Table 3 displays comparative data on somatotypes of taekwondo-in and karateka. The physique of the current group is comparable to that of other American elite junior taekwondo athletes [19, 20]. Although there are sports-specific differences between karate and taekwondo in terms of their energy requirements $[4,5,6]$, the physiques of the junior taekwondo-in are remarkably similar compared to those of adult karateka. The young male and female taekwondo-in are more ectomorphic, while the adult female karateka are more endomorphic than their young counterparts in taekwondo, which is in line with growth and development expectations [7, 16]. 
Table 3. Comparative somatotypes of taekwondo-in and karateka

\begin{tabular}{|l|c|c|}
\hline Sport/Study & Males & Females \\
\hline Taekwondo - Juniors & & \\
\hline This study & $2.19-3.96-3.83$ & $2.88-3.24-3.41$ \\
\hline Pieter [20] & $2.3-4.2-3.5$ & $3.2-3.4-3.1$ \\
\hline Pieter [19] & $2.02-3.96-4.26$ & $2.78-3.26-3.83$ \\
\hline & & \\
\hline Taekwondo - Seniors & $2.5-4.9-2.7$ & -- \\
\hline Olds \& Kang [18] (club) & $2.2-4.5-2.2$ & -- \\
\hline Olds \& Kang [18] (state) & $1.4-4.1-2.0$ & -- \\
\hline Olds \& Kang [18] (elite) & $4.2-4.7-2.9$ & $6.3-4.2-2.0$ \\
\hline Chan et al. [8] & -- & $5.0-4.1-2.5$ \\
\hline Song et al. [24] & $1.74-4.68-3.02$ & $2.47-3.08-3.47$ \\
\hline Pieter [19] & $1.65-4.53-3.59$ & $2.08-3.23-3.98$ \\
\hline Taaffe \& Pieter [25] & & \\
\hline & & \\
\hline Karate - Seniors & $2.0-3.7-2.7$ & $3.4-2.4-2.4$ \\
\hline Fritzsche \& Raschka [12] & $2.3-4.9-2.9$ & $3.6-4.5-2.7$ \\
\hline Fritzsche [11] & $2.5-3.9-3.0$ & $4.4-4.7-1.3$ \\
\hline Amusa \& Onyewadume [1] & $3.07-5.07-1.79$ & -- \\
\hline Krawczyk et al. [15] & $2.6-5.2-2.6$ & -- \\
\hline Claessens et al. [9] & & \\
\hline
\end{tabular}

The same differences are apparent when comparing elite young and elite adult taekwondo-in. For instance, the male junior taekwondo-in are more ectomorphic than their adult colleagues with higher endomorphy $[18,19,20,25]$. The young female taekwondo-in are similar in ectomorphy but higher in endomorphy than their adult colleagues $[19,20,25]$.

Similar physiques are expected of successful young and adult athletes in the same sport [17] as was evident from the global somatotypes. The overlap seems to suggest that at the junior elite level, somatotype plays a role in both males and females, while other factors, such as psychological profile, physiological characteristics and biomechanical efficiency, also have their roles to play in a subjective sport like taekwondo. Physique could then be used as one of the selection criteria to identify and develop talent, keeping in mind tracking issues [16], and the contribution of nutritional considerations and 
optimal training [7] as well as the within-group variation of any of the dimensions of morphological optimization [17].

Data on body build of recreational young taekwondo-in are scarce. Fadzliana et al. [10] described the physique of recreational Malaysian taekwondo practitioners (18 years) and found no statistical differences between males (3.73-5.45-2.34) and females (4.64-4.86-1.44), although the latter had a higher endomorphic and lower ectomorphic rating. When comparing the junior taekwondo athletes in the current study with their adult counterparts competing at lower levels $[8,18$, 24], the difference in the endomorphic component is also evident. This pattern is similar when comparing adult elite and recreational or club taekwondo-in.

It has been suggested that anthropometric determinants in themselves may not be sufficient to predict performance and that experience may play a larger role in the relationship [18]. This was confirmed by Pieter et al. [21], who reported that performance in males was predicted by general taekwondo and competition-specific experience as well as mesomorhy. In the females, performance was related to general taekwondo and competition-specific experience as well as height. Future research should consider physique characteristics in terms of differences in experience, i.e., body build should be investigated taking into account experience.

\section{ACKNOWLEDGMENT}

The support of the author's research assistants during data collection is greatly appreciated.

\section{REFERENCES}

1. Amusa L., Onyewaddume I. (2001) Anthropometry, body composition and somatotypes of Botswana national Karate players: A descriptive study. Acta Kines. Univ. Tart. 6: 7-14.

2. Bayios I. A., Bergeles N. K., Apostolides N. G., Noutsos K. S., Koskolou, M. D. (2006) Anthropometric, body composition and somatotpye differences of Greek elite female basketball, volleyball and handball players. J. Sports Med. Phys. Fit. 46: 271-280.

3. Bender R., Lange S. (2001) Adjusting for multiple testing - when and how? J. Clin. Epidem. 54: 343-349. 
4. Beneke R., Beyer T., Jachner C., Erasmus J., Hütler M. (2004) Energetics of karate kumite. Eur. J. Appl. Physiol. 92: 518-523.

5. Bridge C. A., Jones M. A., Hitchen P., Sanchez X. (2007) Heart rate responses to taekwondo training in experienced practitioners. J. Str. Cond. Res. 21: 718-723.

6. Bouhlel E., Jouini A., Gmada, N., Nefzi, A., Ben Abdallah K., Tabka, Z. (2006) Heart rate and blood lactate responses during taekwondo training and competition. Sci. Sports. 21: 285-290.

7. Carter J. E. L., Honeyman Heath B. (1990) Somaotyping. Development and Applications. Cambridge University Press, Cambridge, UK.

8. Chan K., Pieter W., Moloney K. (2003) Kinanthropometric profile of recreational taekwondo athletes. Biol. Sport. 20: 175-179.

9. Claessens A., Beunen G., Lefevre J., Mertens G., Wellens R. (1986) Body structure, somatotype, and motor fitness of top-class Belgian judoists and karateka. A comparative study. In: Kinanthropometry III, T. Reilly, J. Watkins, J. Borms (eds.). London: E. \& F. N. Spon, 5357.

10. Fadzliana M., Pieter W., Erie Z. Z. (2008) Descriptive anthropometry of recreational adolescent taekwondo practitioners. In: 2008 International Convention on Science, Education and Medicine in Sport. Proceedings Volume I, Guangzhou: People's Sports Publishing House, 28-29.

11. Fritzsche J. (2006) Sportanthropologische Untersuchungen zur Konstitutionstypologie von Kampfkünstlern der Sportart Karate (Elitekarateka). Unpublished Ph.D. thesis, Frankfurt am Main: Johann Wolfgang Goethe Universität.

12. Fritzsche J., Raschka C. (2007) Sportanthropologische Untersuchungen zur Konstitutionstypologie von Elitekarateka. Anthropol. Anz. 65: 1-13.

13. Gualdi-Russo E., Zaccagni L. (2001) Somatotype, role and performance in elite volleyball players. J. Sports Med. Phys. Fit. 41: 256262.

14. Katić R., Blažević S., Krstulović S., Mulić R. (2005) Morphological structures of elite karateka and their impact on technical and fighting efficiency. Coll. Anthropol. 29: 79-84.

15. Krawczyk B., Sklad M., Jackiewics A. (1997) Heath-Carter somatotypes of athletes representing various sports. Biol Sport. 14: 305-310.

16. Malina R. M., Bouchard C., Bar-Or O. (2004) Growth, Maturation, and Physical Activity. Human Kinetics, Champaign, IL.

17. Norton K., Olds T., Olive S., Graig N. (1996) Anthropometry and sports performance. In: Anthropometrica, K. Norton, T. Olds (eds.). Sydney: UNSW Press, 287-364. 
18. Olds T., Kang, S. J. (2000) Anthropometric characteristics of adult male Korean taekwondo players. In: Taekwondo and the New Millennium-Proceedings, Olympic Taekwondo Organizing Committee (ed.). Seoul: Korean National University of Physical Education, 69-75.

19. Pieter W. (1991) Performance characteristics of elite taekwondo athletes. Kor. J. Sport Sci. 3: 94-117.

20. Pieter W. (2001) Somatotypes of young taekwondo athletes: implications for talent identification. In: Proceedings of the 7th International Scientific Conference of the International Association of Sport Kinetics, T. Jürimäe, J. Jürimäe (eds.). Acta Kines. Univ. Tart. 192-195.

21. Pieter W., Mateo C., Bercades L. T. (2002) Determinants of performance in taekwondo. Med. Sci. Sports Exer. 34: S65.

22. Ross W. D., Marfell-Jones M. J. (1991) Kinanthropometry. In: Physiological Testing of the High-Performance Athlete, MacDougall J. D., Wenger H. A., Green H. J. (eds.). Champaign, IL: Human Kinetics Books, 223-308.

23. Rothman K. J. (1990) No adjustments are needed for multiple comparisons. Epidem. 1: 43-46.

24. Song J. K., Sohn D. O., Kim T. W. (1997) Relationship between human physique and physical fitness in collegiate female athletes. In: ICHPER.SD 40th World Congress Proceedings, Seoul, Korea: Kyunghee University, P400 - P402.

25. Taaffe D., Pieter W. (1990) Physical and physiological characteristics of elite taekwondo athletes. In: Commonwealth and International Conference Proceedings. Volume 3. Sport Science. Part 1, Auckland, New Zealand: NZAHPER, 80-88.

26. Wassmer D. J., Mookerjee S. (2002) A descriptive profile of elite U. S. women's collegiate field hockey players. J. Sports Med. Phys. Fit. 42: $165-171$.

\section{Correspondence to:}

Willy Pieter

Department of Physical Education

University of Asia and the Pacific

Ortigas Center

Pasig City 1605

Philippines 